\title{
PLL-BASED 3థ INVERTER CIRCUIT FOR MICROGRID SYSTEM OPERATED BY ELECTROSTATIC GENERATOR
}

\author{
TaWfikur Rahman, S. M. A. Motakabber*, MUhammad IbN Ibrahimy \\ AND AHM ZAHIRUL ALAM \\ Department of Electrical and Computer Engineering \\ International Islamic University Malaysia, \\ PO Box 10, Kuala Lumpur 50728, Malaysia. \\ "Corresponding author: amotakabber@iium.edu.my
}

(Received: $29^{\text {th }}$ Jan 2019; Accepted: $27^{\text {th }}$ March 2019; Published on-line: $1^{\text {st }}$ June 2019)

https://doi.org/10.31436/iiumej.v20i1.1071

\begin{abstract}
A current source control based PLL (phase lock loop) technique is one of the most efficient methods for modern $3 \Phi$ synchronized grid power systems. When an inverter circuit is driven by an electrostatic generator with wind power, it encounters some problems, such as static and dynamic turn-on-off switching losses, unbalanced source voltage, low continuous current, higher frequency harmonic distortion, phase angle imbalance, etc. To solve these problems, a series of connected switching inverter modules technique is proposed. It is not only a traditional inverter system, but it also works as a low-frequency ripple current inverter with lower switch losses. A new topology of phase synchronous inverter (PSI) is designed using a PLL current source controller. The input voltage source of the PSI is a high DC voltage from an electrostatic generator (ESG). The modified ESG is capable of generating the HVDC and a continuous moderate amount of current. The proposed switching topology of the inverter is able to control the microgrid power as well as reduce the dynamic and static switching loss. It also reduces the high-frequency harmonic distortion and improves the phase angle error. The output LCL lowpass filter scheme of the inverter is designed to reduce the total harmonic distortion of $1.62 \%$. The PSI circuit is designed and simulated using MATLAB software. In the developed system, the input voltage of $8 \mathrm{k} V_{\mathrm{DC}}$, microgrid frequency of $50 \mathrm{~Hz}$, switching frequency of the carrier of $10 \mathrm{kHz}$, and modulation index of 0.85 are considered to be implemented. The proposed novel microgrid connected PSI switching module design technique has significantly enhanced the power stability. The overall system efficiency improved by $95.52 \%$.
\end{abstract}

ABSTRAK: Sumber-arus terkawal berdasarkan teknik PLL (fasa litar kunci) adalah satu kaedah cekap bagi sistem moden tenaga grid selaras 3Ф. Apabila litar songsang (inverter) digerak menggunakan penjana elektrostatik bersama tenaga angin, ia mengalami masalah seperti kehilangan tenaga statik dan dinamik suis hidup-mati, sumber voltan yang tidak seimbang, kurang arus terus, gangguan harmoni frekuensi tinggi, ketidak-seimbangan sudut fasa, dan sebagainya. Bagi menyelesaikan masalah ini, teknik modul suis bersiri dihubung bersama inverter telah dicadangkan. Ini bukan semata-mata teknik lama sistem inverter, tetapi ia juga berfungsi sebagai arus tidak tetap frekuensi-rendah dengan kurang kehilangan tenaga pada suis inverter. Topologi baru fasa inverter tetap (PSI) ini telah direka menggunakan kawalan sumber arus PLL. Sumber voltan masuk PSI ini telah digunakan daripada voltan DC tinggi penjana elektrostatik (ESG). ESG yang diubah suai ini dapat menghasilkan HVDC dan arus terus yang sederhana. Topologi suis inverter yang dicadang ini dapat mengawal kuasa mikrogrid 
serta mengurangkan kehilangan dinamik dan statik suis. Ia juga mengurangkan gangguan harmoni frekuensi tinggi dan memperbaiki ketidak-seimbangan sudut fasa. Skim tapisan signal keluar yang rendah pada LCL inverter ini direka bagi mengurangkan total gangguan harmoni sebanyak $1.62 \%$. Litar PSI ini direka dan disimulasi menggunakan perisian MATLAB. Dalam sistem yang dibangunkan ini, $8 \mathrm{kVDCvoltan}$ masuk, $50 \mathrm{~Hz}$ frekuensi mikrogrid, $10 \mathrm{kHz}$ frekuensi suis angkutan dan 0.85 indeks modulasi telah dipertimbangkan untuk kegunaan. Teknik baru modul suis PSI mikrogrid bersambung yang dicadangkan ini mempunyai kepentingan dalam menstabilkan kuasa dan memperbaiki kecekapan sistem keseluruhan sebanyak 95.52\%.

KEYWORDS: PSI; PLL; current controller; PWM controller; inverter switching topology; output LCL filter; microgrid

\section{INTRODUCTION}

A microgrid is a small area power transmission and distribution system that is connected to three-phase synchronous inverters. These are well known to simplify ESG and universally create sustainable power usage [1,2]. Generally, the PLL-based current controller topology is used to control the reactive and active power flow of microgrid systems as described in [2]. The study of current and voltage control strategies of the $3 \Phi$ microgrid-connected, phase-synchronous inverter system is detailed in [3]. It is described as a high voltage and low current microgrid power regulator that is simplified by PLLbased current regulator or voltage control with PWM system [3]. High voltage and low current regulator for $3 \Phi$ microgrid coupled voltage control with PWM are described in, [4-5]. The regulators are applied synchronously, turning in the reference frame utilizing a DC regulator, PI regulator or in $a-b-c$ to $d-q-0$ frame employed deadbeat regulator or hysteresis regulator. A PLL based current regulator system executed in the synchronously turning reference frame is designed in [6]. These papers assume the inverter input voltage from ESG and balance the microgrid voltage and current to microgrid networks. However, with the improvement of the inverted output current study in the area of a microgrid, increasing microgrid current and low higher harmonic frequency distortion is the focus of study.

The voltage source PLL based current regulator for microgrid associated DC to AC inverters is described in [7-8] and the output LCL filter is detailed in [9-10]. In these papers, twin synchronous PLL based current and DC voltage regulators are designed and various types of switching regulator are utilized to create a high voltage and low current regulator in the case of unstable microgrid circumstances. However, the design techniques deal with equal unstable (nonappearance of zero order factor) and stable $3 \Phi$ inverter output LCL filter connection between the PSI and microgrid. A lowpass grid synchronous LCL filter is involved to decrease the low order harmonic frequency distorted current that is a $50 \mathrm{~Hz}$ fundamental frequency [11]. The inverter DC capacitance of the source side is improved in injected ripple current. However, it could be complicated to maximize the size and weight of the system. Alternatively, by including a suitable logic and switching controller circuit, the energetic power is diverted to additional loading energy elements [12]. The loading element of the inverter DC source side of the active power of the filter can carry out a unique low-frequency distorted compensator that is in sequence with the novel inverter. The total energy from the input inverter side can remain constant by appropriately monitoring the current of the additional phase terminal [13]. While these approaches can successfully overpower the input frequency ripple current, the additional inverter switches and circuits may lead to an increase in cost, power losses, and regulator difficulty [14]. 
In this paper, the $3 \Phi$ PSI with PLL based current control in a-b-c to d-q-0 frame is used to reduce the switching loss and increase the output current due to the ESG produced $\mathrm{mA}$ current [15]. A PLL with zero-crossing based regulator is designed to simplify the DC voltage and current regulator as traditional in the a-b-c to d-q-0 frame [12]. That regulator is also designed in a-b-c to d-q-0 reference frame to eliminate the requirement of software PLL in the regulator construction. Furthermore, the proposed regulatory approach is invariant with admiration to the central frequency of the microgrid [16]. The proposed switching regulator technique has utilized the current and voltage references that the method is defined in [3]. In addition, a grid synchronous LCL lowpass filter is usually utilized to reduce switching loss and reduction ripple, to improve the phase angle error, and to increase the inverter system efficiency [17]. The inverter must be synchronized, and noise should be reduced in terms of its output voltage and current waveform because the inverter performance depends on noiseless power quality and power density. Therefore, the output filter is used to couple the inverter and microgrid for synchronization purposes by reducing the higher harmonic distortion.

The effective current and voltage tracking by the voltage source controller with PWM confirms suitable microgrid current and voltage flow along with input DC ripple current and pure sinusoidal microgrid waveform. The study of the proposed regulator and inverter output LCL filter are provided and acceptable simulations are also carried out to show the overall system efficiency of the proposed systems.

\section{DESIGN OF A PSI INTERFACE WITH MICROGRID SYSTEMS}

Conventionally, this inverter circuit consists of three half H-bridge single-phase inverter switches each connected to one of the three load terminals. For the preliminary control system, the operation of the solid state or mechanical three phase switches are synchronized in order for one switch to work at each $60^{\circ}$ of the fundamental output waveform. Fig. 1 illustrates the block diagram of a $3 \Phi$ PSI with an electrostatic generator and a microgrid system.

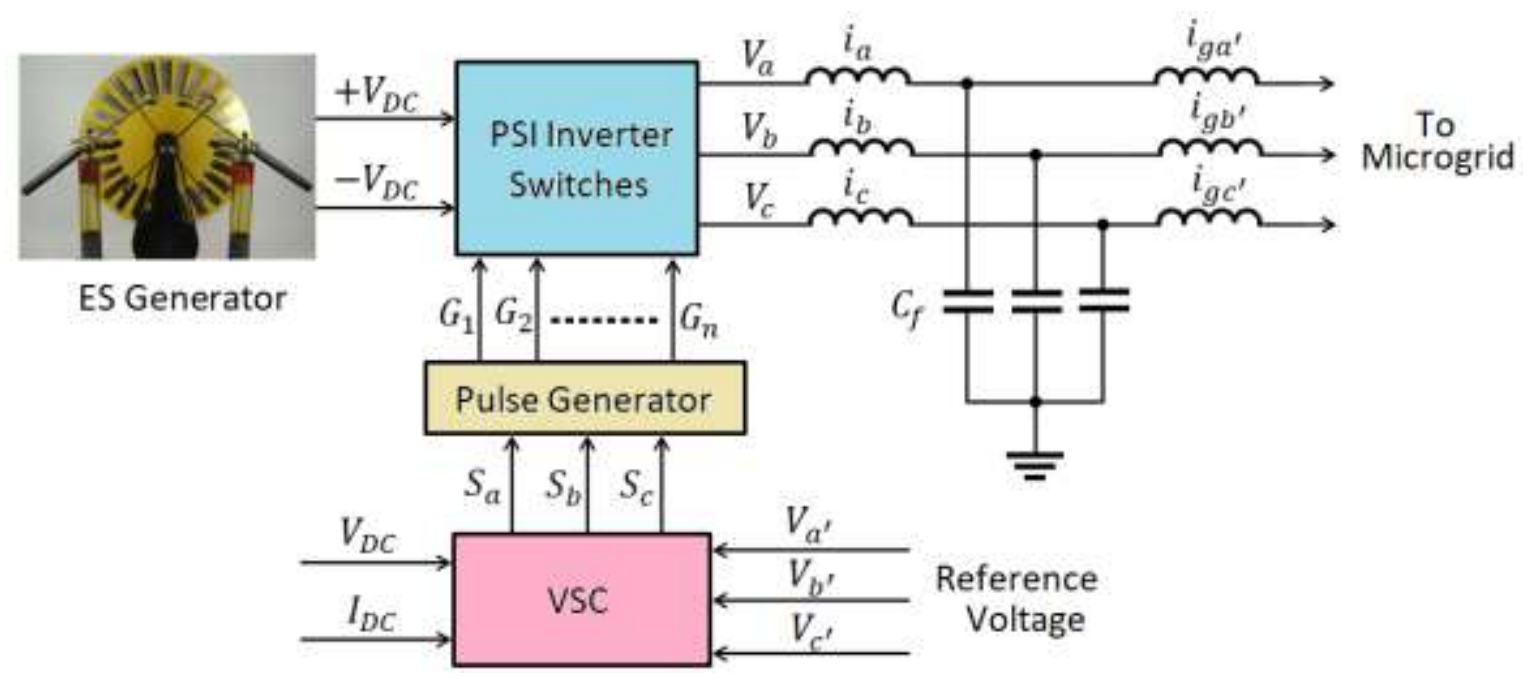

Fig. 1: Proposed ESG powered PSI circuit for $3 \Phi$ microgrid systems.

The efficient specifics of the diagram are investigated in [3]. To the existing microgrid systems, this represents some significant improvements like power quality, bulky line-frequency transformer, power density, high controllability, flexibility, and high 
efficiency, etc. The PSI connected micro-grid technology is a capable solution to integrate a lot of energies and energy storage systems, which calls for more controllable and more flexible smart grids [12]. On the power delivery level, the voltage-source inverter, currentsource inverter, zero voltage source inverter, voltage direct-current transmission systems are a developing technology to integrate small static power such as offshore PV or wind farms coupled electrostatic generator systems.

In the modern world, energy demand is one of the most important key factors in every sector of our daily life. Conventionally, the electromagnetic system is employed to create electrical energy. However, ESG can also be utilized to produce high electrical static DC voltage. The main drawback of such generators is their limited and specific applications in the power generation and distribution systems. However, the ESG-based inverter system can overcome these limitations by converting DC to AC electrical power.

\section{MATHEMATICAL ANALYSIS OF 3Ф PSI SYSTEMS}

Three-phase inverters are widely utilized for microgrid systems because of rising power demand, developing the power quality, and the potential benefits to end users. To simplify the PSI design of the microgrid connected ESG, Fig. 1 shows the shortened model and that model is further demonstrated in Fig. 2. It is distinguished that the input DC sources link mutual point " $O$ " is isolated from $3 \Phi$ microgrid neutral point " $N$ ". Two input sources are taken such as $+V_{D C} / 2$ and $-V_{D C} / 2$. The mutual point " $O$ " is connected to the two input DC sources. The inductor of the inverter side as well as the microgrid side is distorted and harmonics. The line current of each phase is written as analysis given in [3]:

$$
\begin{aligned}
& L a \frac{d_{i_{C a}}}{d t}+R_{a} i_{C a}=v_{i n v a}-v_{m g a} \\
& L b \frac{d_{i_{C b}}}{d t}+R_{b} i_{C b}=v_{i n v b}-v_{m g b} \\
& L c \frac{d_{i_{C c}}}{d t}+R_{c} i_{C c}=v_{i n v a}-v_{m g c}
\end{aligned}
$$

where, $v_{i n v a}, v_{i n v b}$ and $v_{i n v c}$ are the specific PSI output voltage regarding the microgrid neutral " $\mathrm{N}$ " point while $v_{m g} a, v_{m g b}$ and $v_{m g}$ are the individual microgrid voltages regarding the microgrid " $\mathrm{N}$ " point, correspondingly. In this case, microgrid neutral point "N" is isolated from the two input DC sources mutual point "O", the three phase currents can be followed as:

$i_{C a}+i_{C b}+i_{C c}=0$

Subtracting Eq. (3) from (1) and (2) using Eq. (4), resulting Eq. with line quantities are derived:

$$
\begin{aligned}
& L a \frac{d_{i_{C a}}}{d t}+L a \frac{d\left(i_{C a}+i_{C b}\right)}{d t}+R_{c}\left(i_{C a}+i_{C b}\right)+R_{a} i_{C a}=v_{\text {invac }}-v_{m g a c} \\
& L a \frac{d_{i_{C b}}}{d t}+L c \frac{d\left(i_{C a}+i_{C b}\right)}{d t}+R_{C}\left(i_{C a}+i_{C b}\right)+R_{b} i_{C b}=v_{i n v b c}-v_{m g b c}
\end{aligned}
$$


where, $v_{i n v y y}$ and $v_{m g y y}$ are consistent PSI and microgrid phase voltages respectively. Therefore, the independent states space equation, for example, $i_{C a}=y_{1}$ and $i_{C b}=y_{2}$ and solving Eq. (5) and (6) the resulting Eq. are initiated [3-4].

$\frac{d_{y_{1}}}{d t}=a_{11} y_{1}+a_{12} y_{2}+b_{11} v_{i n v a c}+b_{12} v_{i n v b c}+m_{1}$

$\frac{d_{y_{2}}}{d t}=a_{21} y_{1}+a_{22} y_{2}+b_{21} v_{i n v a c}+b_{22} v_{i n v b c}+m_{2}$

Eq. (7) has been improved Eq. (8).

$\frac{d_{y_{1}}}{d t}=a_{11} y_{1}+a_{12} y_{2}+x_{1}+m_{1}$

$\frac{d_{y_{2}}}{d t}=a_{21} y_{1}+a_{22} y_{2}+x_{2}+m_{2}$

The inputs control $x_{1}$ and $x_{2}$ are specified in relations phase to phase voltages $V_{i n v a b}$ and $V_{\text {inv } b c}$ as represented in Eq. (8).

$$
\begin{aligned}
& {\left[\begin{array}{l}
x_{1} \\
x_{2}
\end{array}\right]=\left[\begin{array}{ll}
b_{11} & b_{12} \\
b_{21} & b_{22}
\end{array}\right]\left[\begin{array}{l}
v_{\text {inv } a c} \\
v_{\text {inv } b c}
\end{array}\right]} \\
& \Rightarrow\left[\begin{array}{l}
v_{\text {inv } a c} \\
v_{\text {inv } b c}
\end{array}\right]=\frac{\left[\begin{array}{cc}
b_{11} & -b_{12} \\
-b_{21} & b_{22}
\end{array}\right]}{b_{11} b_{22}-b_{12} b_{21}}\left[\begin{array}{l}
x_{1} \\
x_{2}
\end{array}\right]
\end{aligned}
$$

where $x_{1}$ and $x_{2}$ are observed as the trouble inputs to the state space Eq. demonstrated in Eq. (6) and (7).

\section{DESIGN OF A CONTROL METHOD FOR 3Ф PSI TOPOLOGY}

Two DC voltage sources connected in series may be implemented using one PSI. The logic switching control circuit must produce zero-crossing gate pulses from the twodifferent reference signals. The pulse signal is sent to the IGBT module. It can produce three-terminal phase voltages, namely $v_{a o}, v_{b o}$ and $v_{c o}$ which are square-waves. During the operating period, the circuit has six different states. Three modules drive each state. When a module is turned on, another module turns off. The load voltage is regulated from zero to its maximum by changing the angle $\Psi$. In addition, the LCL lowpass filter is used to convert square waves into a modified sine wave with low frequency higher harmonic distortion. Figure 2 shows the PSI power circuit block diagram of the $3 \Phi$ microgrid connected ESG system. Form the Eq. (7) and (8), it is observed that the $3 \Phi$ microgrid connected ESG system consists of two conditions, $y_{1}$ and $y_{2}$. 


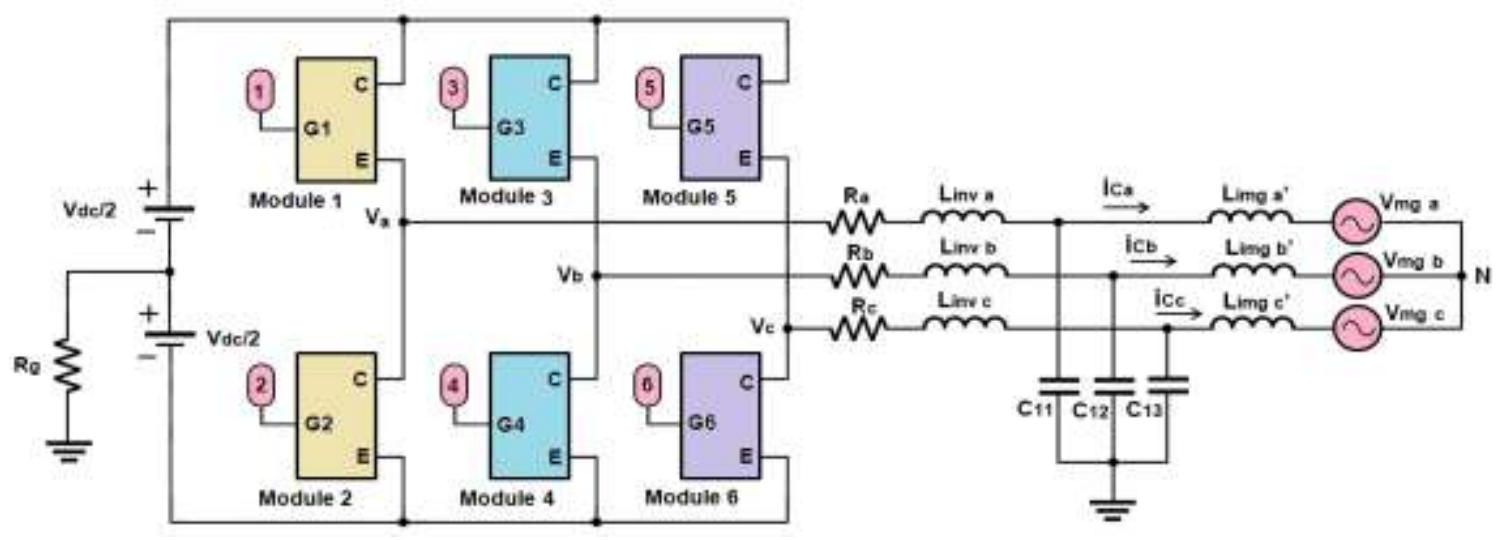

Fig. 2: Shortened PSI circuit of the $3 \Phi$ microgrid connected ESG systems.

Considering a positive definite function [5] as demonstrated in Eq. (11).

$$
U=\frac{e e^{T}}{2}
$$

Where $e$ is the error array highlighted in Eq. (11).

$$
e=\left[\begin{array}{l}
e_{1} \\
e_{2}
\end{array}\right]=\left[\begin{array}{ll}
y_{1}^{\prime}- & y_{1} \\
y_{2}^{\prime}- & y_{2}
\end{array}\right]
$$

where, $y_{1}^{\prime}$ and $y_{2}^{\prime}$ are the following references of $y_{1}$ and $y_{2}$ respectively. At first, assuming no disturbances, such as $m_{1}=m_{2}=0$ : Applying Eq. (8), $U$ is the first-time derivative exposed in Eq. (13).

$$
\frac{d U}{d t}=e^{T}\left[\begin{array}{l}
\frac{d y_{1}^{\prime}}{d t}-a_{11} y_{1}-a_{12} y_{2}-x_{1} \\
\frac{d y_{2}^{\prime}}{d t}-a_{21} y_{1}-a_{22} y_{2}-x_{2}
\end{array}\right]
$$

The finding of the stability of the Lyapunov function method must be a negative function as given in Eq. (14).

$$
\begin{aligned}
& \frac{d U}{d t}=-e^{T} \tau e \\
& \tau=\left[\begin{array}{cc}
\psi_{1} & 0 \\
0 & \psi_{2}
\end{array}\right]
\end{aligned}
$$

where, $\psi_{1}$ and $\psi_{2}$ are the positive quantity. Comparing Eq. (13) and (14), the control variables are resolved as followed by Eq. (16) and (17).

$$
\begin{aligned}
& x_{1}=\frac{d y_{1}^{\prime}}{d t}-a_{11} y_{1}-a_{12} y_{2}+\psi_{1} e_{1} \\
& x_{2}=\frac{d y_{2}^{\prime}}{d t}-a_{21} y_{1}-a_{22} y_{2}+\psi_{2} e_{2}
\end{aligned}
$$


Secondly, assuming microgrid voltage disturbance such as $m_{1} \neq m_{2} \neq 0$ : the first derivative is considered of Lyapunov function $U$ and employing state space Eq. (8) and the input array as demonstrated in Eq. (16 and 17), Eq. (18) is written.

$$
\begin{aligned}
\frac{d U}{d t} & =e^{T} \frac{d e}{d t} \\
& =\left[\begin{array}{ll}
-e_{1} \psi_{1} & -m_{1} \\
-e_{2} \psi_{2} & -m_{2}
\end{array}\right]
\end{aligned}
$$

If both Eq. 20 and 21's conditions are justified, then Eq. (19) is first derived from the Lyapunov function $(U)$. This function is negative and definite in the absolute error designed $e_{1 b}$ and $e_{2 b}$ of $\mathrm{e}_{1}$ and $\mathrm{e}_{2}$ correspondingly.

$$
\begin{aligned}
& \psi_{1}>\frac{\left|m_{1}\right| \text { max }}{e_{1 b}} \\
& \psi_{2}>\frac{\left|m_{2}\right| \text { max }}{e_{2 b}}
\end{aligned}
$$

Therefore, the design of the control law presented in Eq. 16 and 17 is enough to push the state-error into the error designed $e_{1 b}$ and $e_{2 b}$. The inverter parameter uncertainty is solved by selecting appropriate gain which are $\psi_{1}$ and $\psi_{2}$. Fig. 3 shown in the PLL based PSI switching controller.

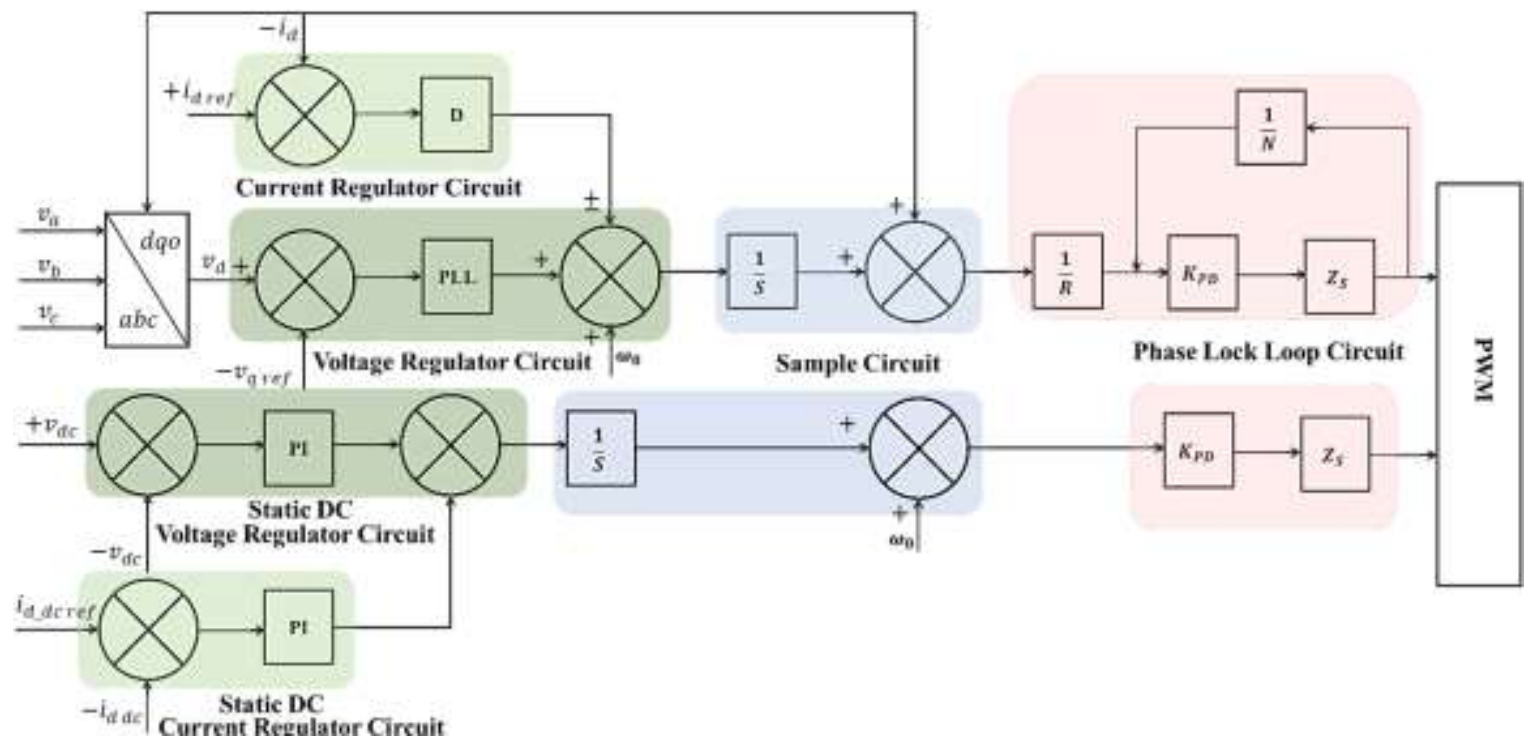

Fig. 3: The MATLAB block diagram of the PSI switching controller.

The controller includes three synchronous pulse voltages to operate the series switching module. Two modules are connected to one terminal. Every terminal is determined like the next and lagged by $\frac{2 \pi}{3}$ degree interval. Each switching module drives for $180^{\circ}$. From Eq. 20 and 21, it is observed that during the functioning period, the circuit is eight different switching logic states while two logic states are considered. The conducting period is called blanking time. Three switches drive in each state. When a switch is opened, another switch is closed. This drives a new current path and a new circuit logic state. 


\section{DESIGN OF THE PSI OUTPUT LCL FILTER}

A three-pole lowpass filter is presented to reduce the ripple current of the switches and improve the phase oscillations [10]. The designed filter is utilized to reduce DC ripple and noise. Figure 4 presents the lowpass filter, where inductor $\mathrm{L}_{\text {inv }}$ is interconnected with the inverter side while inductor $\mathrm{L}_{\mathrm{mg}}$ is corporate with the microgrid-side and $\mathrm{C}_{\mathrm{f} 1}$ is a capacitor.

Equations 22 and 23 define the base capacitance and impedance and both parameters' relation refer to the percentage of the base values [7-9].

$$
\begin{aligned}
& C_{\text {base }}=\frac{1}{\omega_{m g} Z_{\text {base }}} \\
& Z_{\text {base }}=\frac{U_{n}^{2}}{P_{n}}
\end{aligned}
$$

where, $V_{L-L}$ and $V_{p}$ are inverter output voltage, $f_{0}$ is microgrid frequency, $P_{n}$ is nominal power, $f_{s w}$ is switching frequency.

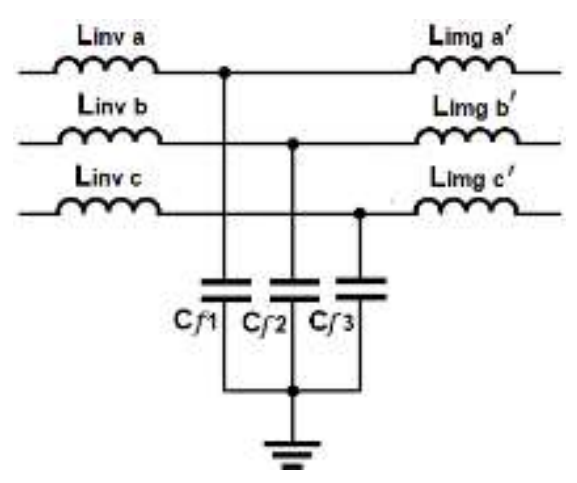

Fig. 4: Schematic diagram of the LCL lowpass filter.

Maximum 5\% power factor sweeping is taken to design the filter capacitance that percentage is performed by the microgrid. That factor indicates the system base impedance is adjusted to $C_{f 1}=0.05 \mathrm{C}_{\text {base }}$. Another researcher is taken a higher power factor to compensate for the inductive reactance of the filters [9-10].

$\Delta i_{\text {Lmax }}=\frac{V_{D C}}{6 f_{s w} L_{\text {inv }}}$

The filter is designed in such a way that ripple current would be $15 \%$ calculated by

$\Delta i_{\text {Lmax }}=0.15 i_{\max }$

For phase voltage $V_{p h}$ the $i_{\text {max }}$ and $L_{i n v}$ can be written by Eq. (26) and Eq. (27)

$$
\begin{aligned}
& i_{\text {max }}=\frac{\sqrt{2} P_{n}}{3 V_{p h}} \\
& L_{i n v}=\frac{V_{D C}}{6 f_{s w} \Delta i_{L \max }}
\end{aligned}
$$


The ratio (r) is constant for both sides of the inductor. Therefore,

$L_{m g}=r L_{i n v}$

$R_{f}$ is the damping resistor that is incorporated with the series capacitor to reduce the ripple current on the switching frequency [8-11]. $k_{1}$ represents the $20 \%$ attenuation factor. LCL filter capacitance value is found out by the following Eq. (32). Therefore,

$$
\begin{aligned}
& L_{m g}=\frac{\sqrt{1 / k_{1}^{2}+1}}{C_{f} \omega_{s w}^{2}} \\
& \omega_{r e s}=\sqrt{\frac{L_{i n v}+L_{m g}}{L_{i n v} L_{m g} C_{f 1}}} \\
& 15 f_{m g}<f_{\text {res }}<0.5 f_{s w} \\
& R_{f}=\frac{1}{3 \omega_{\text {res }} C_{f 1}}
\end{aligned}
$$

If the output lowpass filter inverter side inductor of $L_{i n v}$ and microgrid side inductor of $L_{M G}$ is considered constant, then their ripple current is not surpassed. However, the microgrid inductor of $L_{M G}$ can have a large set of values. Based on microgrid LCL lowpass filter, the ratio of $\frac{R_{M G}}{X_{M G}}$ varies according to the high voltage line microgrid configuration with wires length and conditions. It is also consisted of the leakage inductance of the inductors, whereas the filter capacitor value produced a small amount of error which depends on capacitor accuracy. Typically, the small value of the capacitors have an accuracy varying between 5\% and 20\%. THD is the RMS value of the total higher harmonics current [7-9], divided by the RMS value of its fundamental current, where the equation is as follows:

$M=\frac{\text { Harmonic Magnitude }}{\sqrt{2}}$

$\% T H D=\frac{\sqrt{\sum_{i=2}^{n} M_{i}^{2}}}{M_{1}}$

where, $M_{i}$ is RMS value of the harmonic magnitude corresponding to the $i^{\text {th }}$ harmonic.

\section{EXPERIMENTAL SETUP}

To attain the improved design, series switching based PSI switching modules were constructed utilizing 40WR21 IGBT with a 4N35 optocoupler, controlling the required input $8 k V_{D C}$ static DC voltage. In this case, series switching IGBT modules are regulated using an Arduino Uno microcontroller.

In addition, E55/28/21-N87 cores with 400000 turns, coil length of $127 \mathrm{~mm}$ and coil diameter of $32 \mathrm{AWG}$, achieving the required $0.5 \mathrm{H}$ inductance value. The output LCL filter was implemented using three inductors of $0.5 \mathrm{H} / 1$ A with the plastic resistance of $164 \Omega$ connected in inverter side, three capacitors of $2.5 \mu \mathrm{F}$ and three inductors of $0.45 \mathrm{H} / 1 \mathrm{~A}$ with the plastic resistance of $164 \Omega$ connected in microgrid side. 


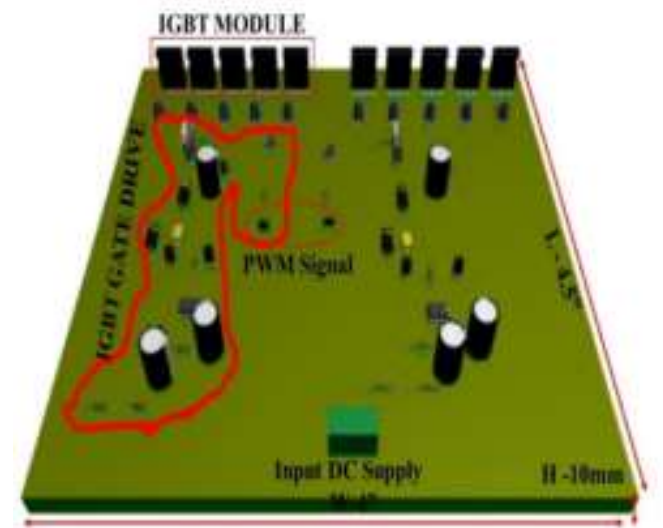

(a)

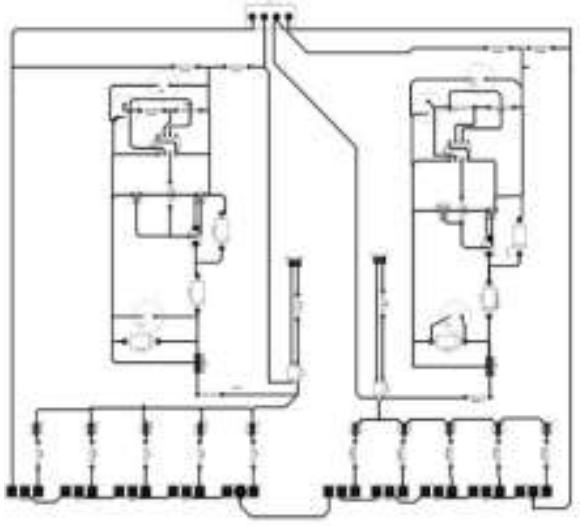

(b)

Fig. 5: Prototype half phase PSI circuit, (a) 3D, (b) PCB layout.

\section{RESULTS AND DISCUSSION}

\subsection{Simulated Results and Discussion}

The PSI circuit demonstrated in Fig. 2 along with a control structure that is illustrated in Fig. 5 is simulated by MATLAB2016a /Simulink. For both switching turn-on and turnoff conditions and considered $\mathrm{I}_{\mathrm{C}}$ current is $400 \mathrm{~A}$, then energy loss may be $500 \mathrm{~mJ}$ at 25 ${ }^{\circ} \mathrm{C}$, however, in the case of $125^{\circ} \mathrm{C}$, energy loss is $600 \mathrm{~mJ}$. From the IGBT On-state characteristics, it is observed that when $V_{C E}$ is $3.25 \mathrm{~V}$ then current $I_{C} 500 \mathrm{~A}$ while $V_{C E}$ is equal to $4.5 \mathrm{~V}$ then $I_{C}$ current should be same, $500 \mathrm{~A}$.
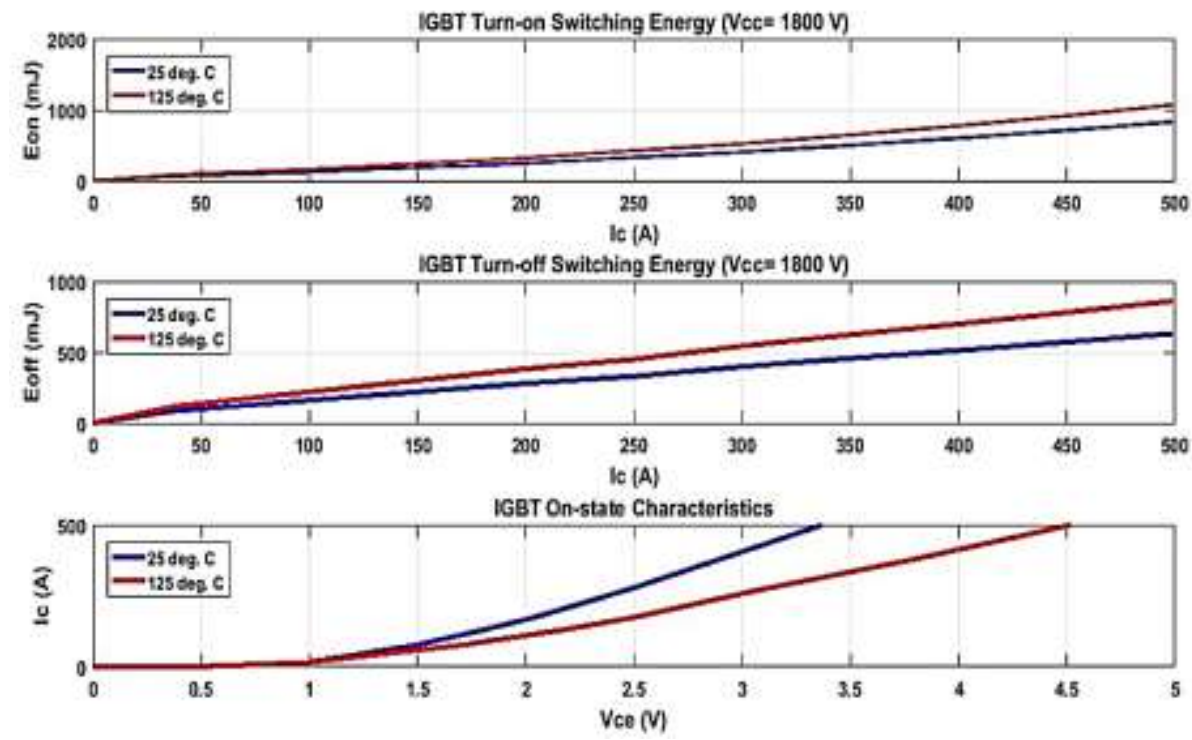

Fig. 6: Turn on and off switching energy of the IGBT.

In addition, the diode reverse recovery energy and diode On-state characteristics are presented in Fig. 6 . For both $25^{\circ} \mathrm{C}$ and $125^{\circ} \mathrm{C}$, energy loss is gradually increased from the current $50 \mathrm{~A}$ to $450 \mathrm{~A}$. In the case of $450 \mathrm{~A}$, energy loss approximately $200 \mathrm{~mJ}$ at $25^{\circ} \mathrm{C}$ whereas energy loss is $330 \mathrm{~mJ}$ at $125^{\circ} \mathrm{C}$. Fig. 9 shows that the diode is forward current at $25^{\circ} \mathrm{C}$ and $125^{\circ} \mathrm{C}$. If the current is almost $500 \mathrm{~A}$, the maximum $V_{f}$, voltage is found $2.4 \mathrm{~V}$ and $2.7 \mathrm{~V}$ voltage, respectively. 

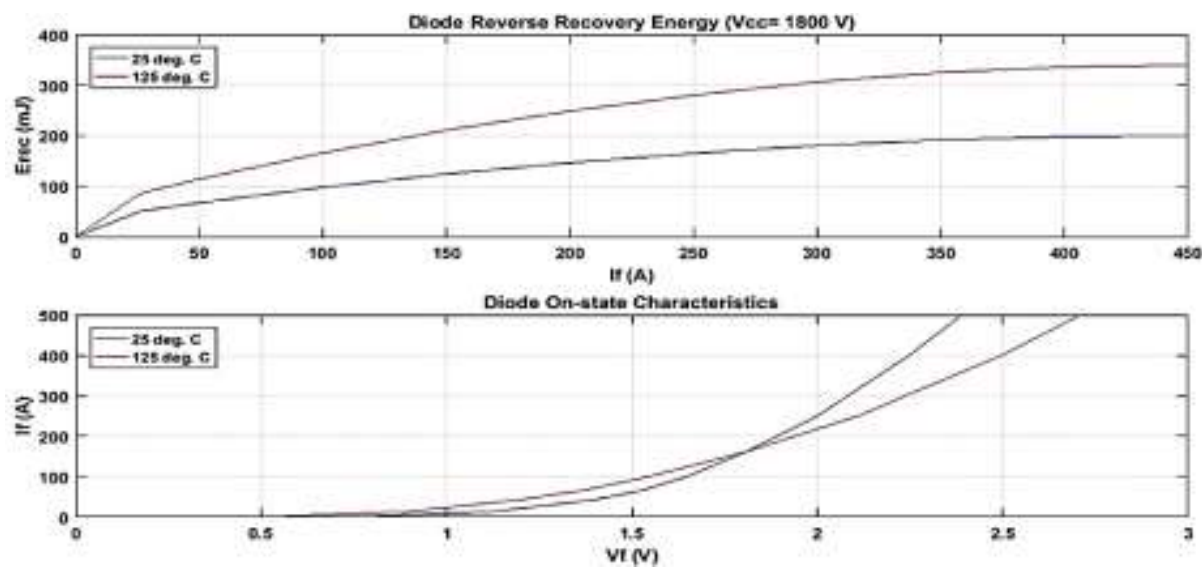

Fig. 7: Turn on and off switching energy diode.

In order to simulate the increased inverter output current using a series switching strategy with PLL based current controller from Eq. 20 and 21, the conventional voltage source control method is modified and presented in Fig. 3. The PWM switching frequency of the PSI is kept at $f_{w s}=10 \mathrm{kHz}$. The parameters of the proposed control are applied in the simulation, proportional gain of the current loop $K_{p}=0.3$, an integral gain of the current loop $K_{i}=20$, proportional gain of the DC-link voltage loop $K_{V d c} \mathrm{P}=7$, an integral gain of the dc-link voltage loop $K_{V D C} \mathrm{i}=800$, nominal DC voltage $8 \mathrm{k} V_{D C}$, sampling time $5 \times 10^{-6} \mathrm{~s}$ and the number of sampling per cycle is 3240 to generate the inverter output voltage and current. The distorted output voltage and current waveform of the PSI are shown in Fig. 8. It is clearly seen that the voltage is $V_{a b c}=5443 V_{r m s}$ and the current is $I_{a b c}=282.8 \mathrm{~A}(\mathrm{rms})$ whereas the fundamental frequency is $50 \mathrm{~Hz}$.

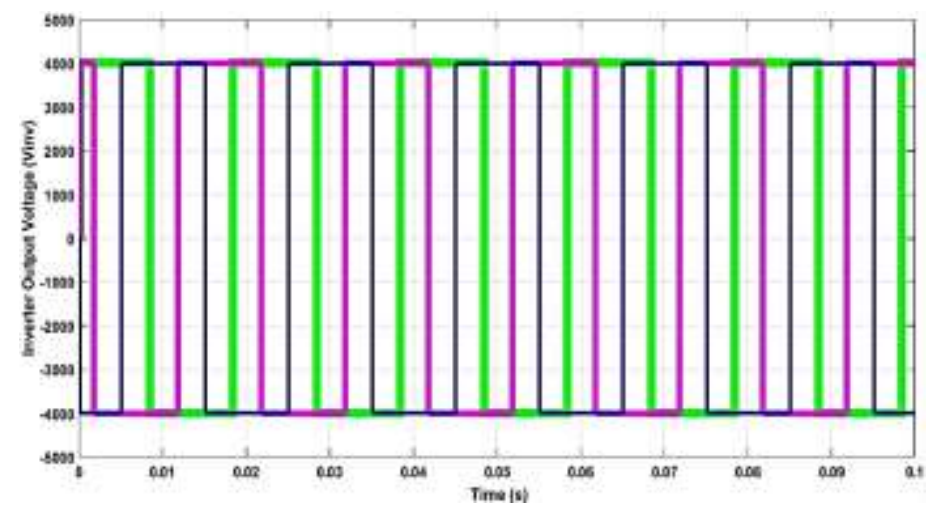

(a)

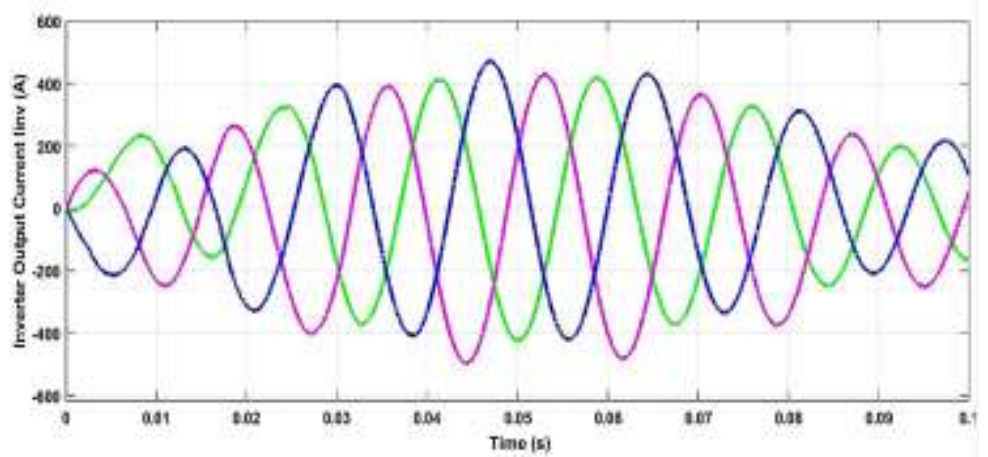

(b)

Fig. 8: Inverter output waveforms, (a) voltage, (b) current. 
The output LCL filter is carried out in a microgrid connected PSI based on Eq. 9 and 10 , in order to demonstrate the concert under PLL based current control. The microgrid voltage and current waveform with the filtering condition are shown in Fig. 9 (a) and (b). In this case, the microgrid output voltage and current are around $8 \mathrm{k} V_{r m s}$ and almost 26.22 A (rms), respectively, considering fundamental frequency $50 \mathrm{~Hz}$.

An FFT analyzer based on Eq. 33 is used to analyze \% THD. Without the filtering condition, the THD of the inverter output injected voltage and current are shown in Fig. 10 (a) and (b). It is observed that the inverter output phase voltage $\left(V_{a} \mathrm{rms}\right)$ and current $\left(I_{a}\right.$ rms $)$ are $-7.09 \mathrm{~dB}(\mathrm{THD}=43.90 \%)$ and $-7.08 \mathrm{~dB}(\mathrm{THD}=43.95 \%)$, respectively.

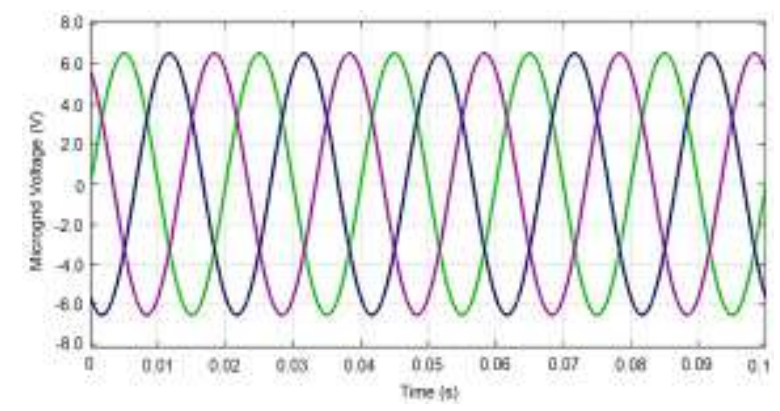

(a)

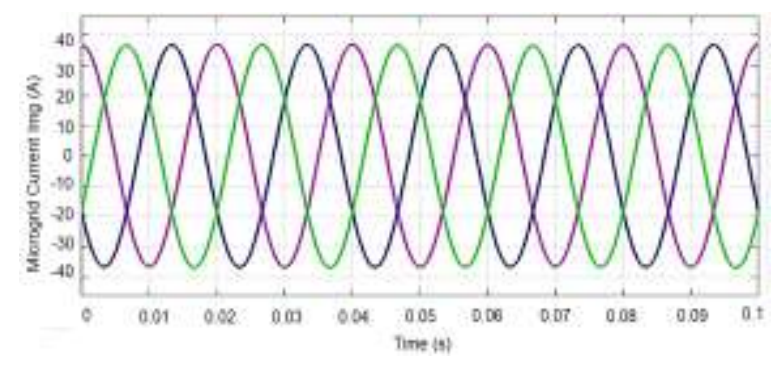

(b)

Fig. 9: Microgrid waveform, (a) voltage $V_{a b c}$, (b) current $I_{a b c}$.

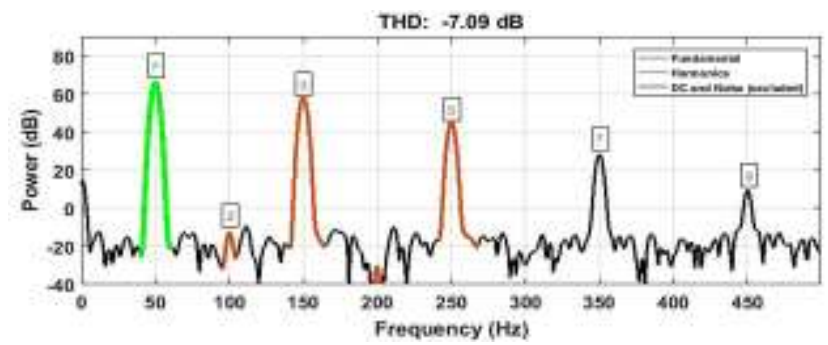

(a)

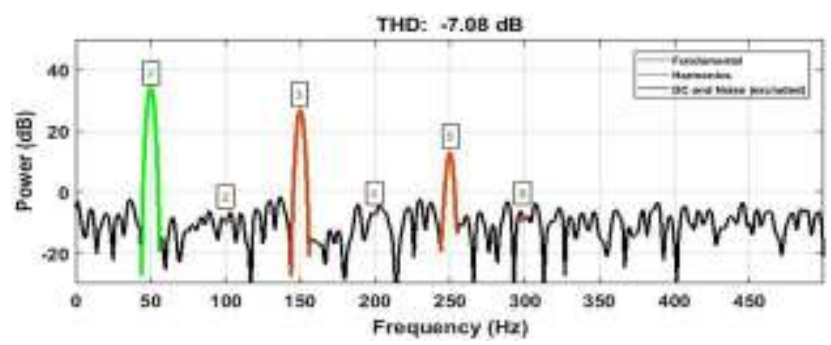

(b)

Fig. 10: FFT analysis of the inverter output, (a) voltage $V_{a}$, (b) current $\left(I_{a}\right)$. 
Microgrid harmonic spectrum of injected voltage and current with filtering conditions are shown in Fig. 11 (a) and (b). It is seen that injected voltage and current are $-35.87 \mathrm{~dB}$ and $-35.76 \mathrm{~dB}$, respectively. So, the microgrid output THD voltage and current are $1.61 \%$ and $1.62 \%$.

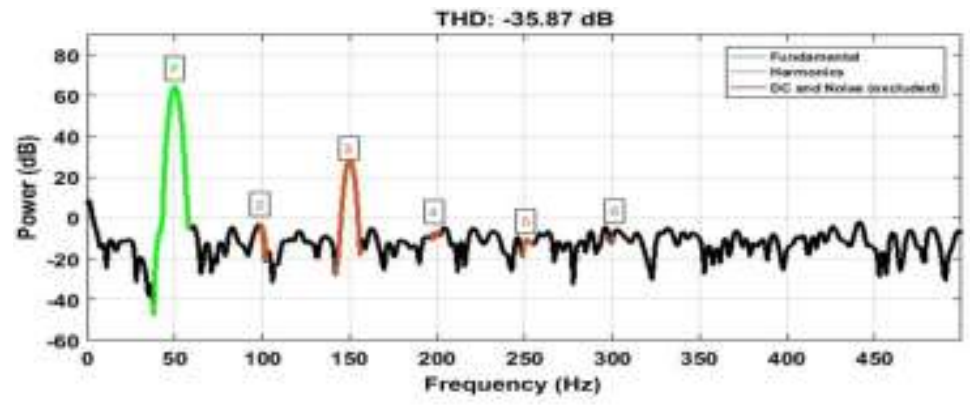

(a)

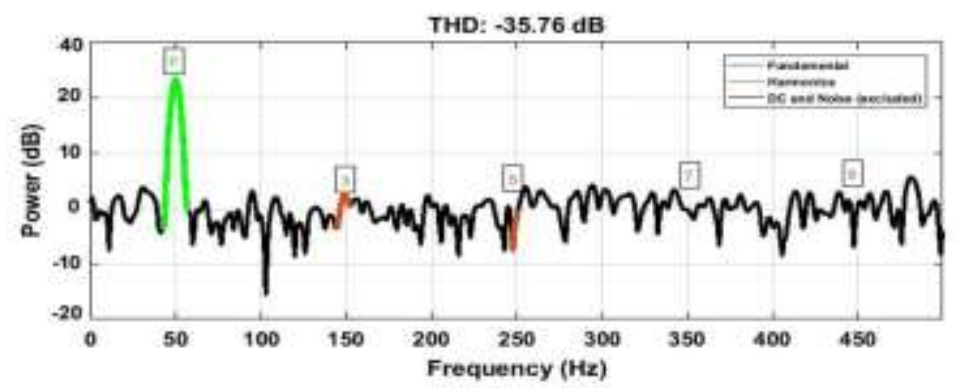

(b)

Fig. 11: FFT analysis for microgrid (a) voltage $V_{a}$ and (b) current $\left(I_{a}\right)$.

Figure 12 shows the microgrid magnitude and phase waveform. In this case, the systems are used the switching frequency of $10 \mathrm{kHz}$, duty cycle $85 \%$, sample per cycle of 3240 and microgrid fundamental frequency of $55 \mathrm{~Hz}$. It should be noted that the microgrid voltage phase angles with the filtering condition are $V_{a b}-V_{b c}$ of $4.39^{\circ}, V_{b c}-V_{c a}$ of $124.50^{\circ}$, $V_{c a}-V_{a b}$ of $-115.78^{\circ}$, correspondingly. The without-filtering condition, the inverter output voltages are $V_{a b}-V_{b c}$ of $34.39^{\circ}, V_{b c}-V_{c a}$ of $154.50^{\circ}, V_{c a}-V_{a b}$ of $-85.78^{\circ}$, respectively. However, the magnitude and phase of the LCL output phase to ground $V_{a b c}$ is almost the same as $I_{a b c}$.

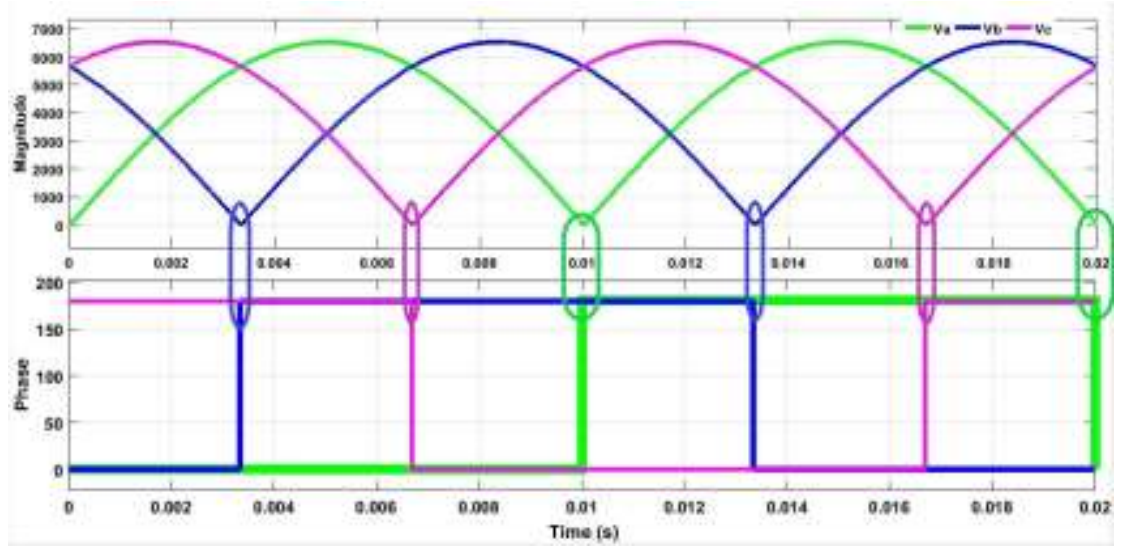

Fig. 12: The microgrid output voltage magnitude and phase. 
Finally, the simulated result has shown that the proposed inverter phase is almost equal to the microgrid phase of the designed PLL based synchronization technique and therefore the phase error is only $4.39^{\circ}$

\subsection{Experimental Results and Discussion}

To establish the experimental set-up, the control switching frequency is set to $10 \mathrm{kHz}$ of the microcontroller and the input reference voltage $V_{D C}$ was performed to $8 \mathrm{k} V_{D C}$ from the electrostatic generator. Based on the switching controller, the inverter output voltage and current waveform without filtering conditions are almost the same as simulated results as demonstrated in Fig. 13.

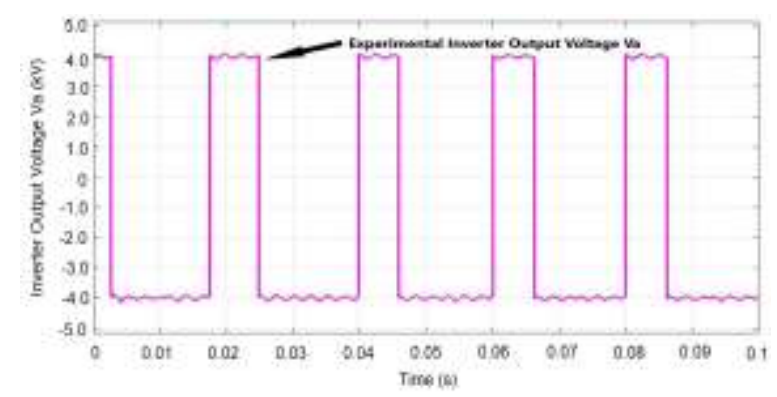

(a)

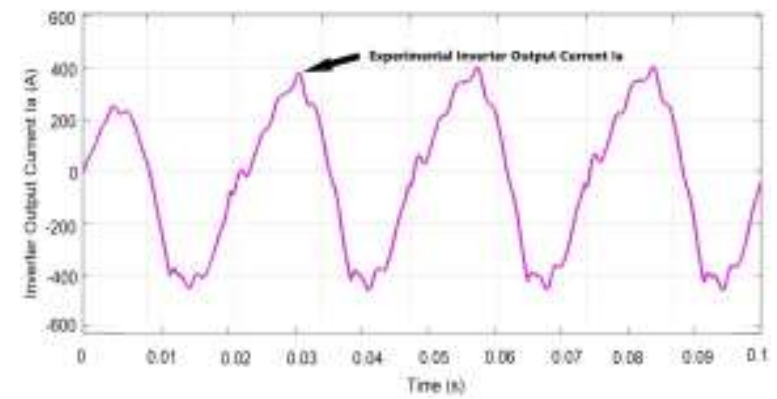

(b)

Fig. 13: Output waveforms of the PSI, (a) voltage, (b) current.

It is clearly seen that the experimental results of the inverter output voltage and current are $4 \mathrm{kV}$ peak and $400 \mathrm{~A}$ peak, respectively. After filtering, the microgrid voltage and current are around $6 \mathrm{kV}$ and $30 \mathrm{~A}$ peak which is almost similar to simulated results as depicted in Fig. 14. According to Fig. 14, it is observed that both waveforms are cut the same point of $0.02 \mathrm{~s}$ which is $50 \mathrm{~Hz}$ of fundamental microgrid frequency. Similarly, it should be renowned that the experimental results are attained without damping technique. The inverter output voltage and current THD is equal to $44 \%$ without filtering condition, while the microgrid voltage and current THD is almost equal to $2 \%$ with filtering condition.

As represented in Fig. 15, the voltage and current frequency distortion and the THD value are decreased utilizing microgrid based lowpass LCL output filter. Moreover, the gained microgrid voltage and current THD is less than $<5 \%$ which meets microgrid code requirements. Figure 15 shows the FFT analysis of the measured inverter and microgrid voltages and currents. From these figures, the largest near fundamental and switching frequency voltage and current harmonic components are equal to $43.98 \%$ on the inverter 
side and $1.67 \%$ on the microgrid side. Therefore, the higher frequency harmonic attenuation rate of $\delta$ is equal to $26 \%$.

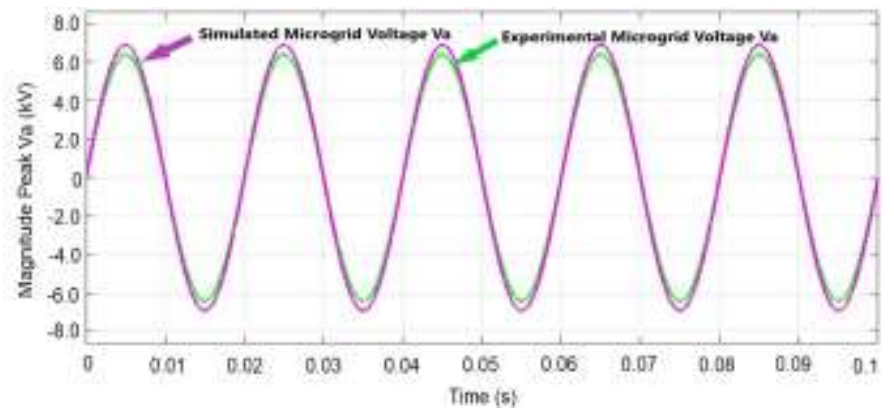

(a)

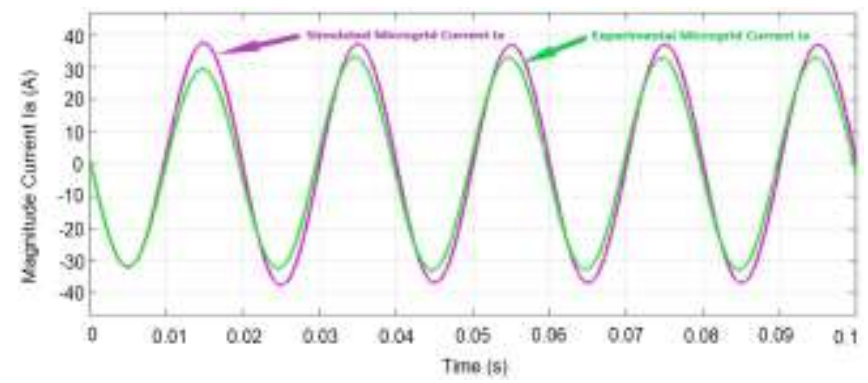

(b)

Fig. 14: The voltage and current of the microgrid (a) simulated, (b) experimental.

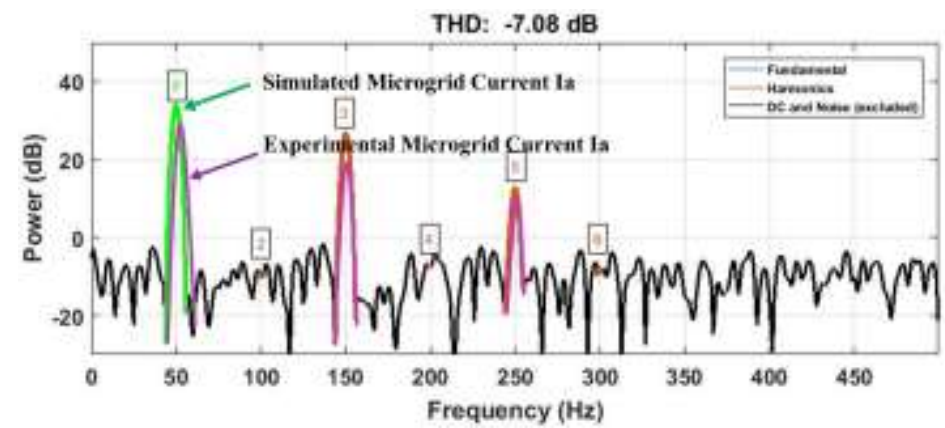

(a)

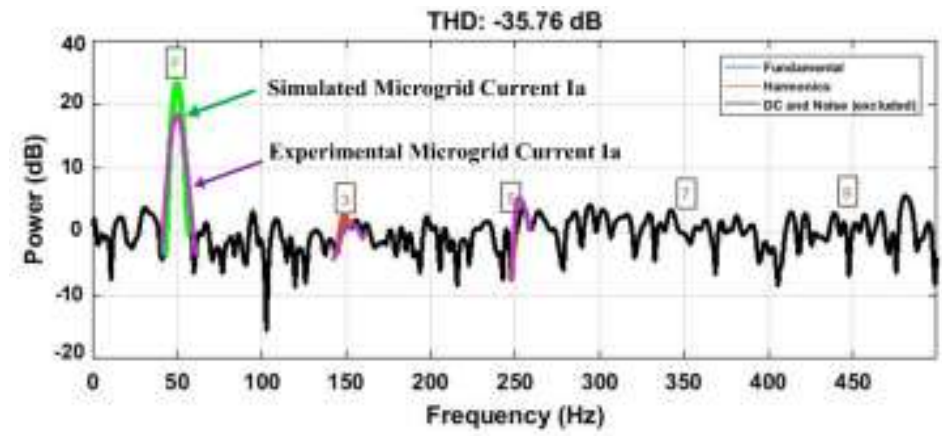

(b)

Fig. 15: FFT analysis of microgrid current, (a) simulated, (b) experimental.

Figure 16 illustrates the output waveforms of the microgrid line to line voltage of $V_{a M G}$ with respect to the microgrid line to line current of $i_{a M G}$ during steady state operation. In this case, the power factor is close to the unity power factor then the 
microgrid output voltage and current are in phase. However, these odd frequency harmonics ripple could be avoided then the DC ripple current come from sensors harmonic and the peripheral current control loop of the static high voltage DC of $V_{D C}$. In conclusion, it is found that a PLL based synchronous controller provides high performance with minimized switching loss, reduced harmonic distortion and synchronized phase angle.

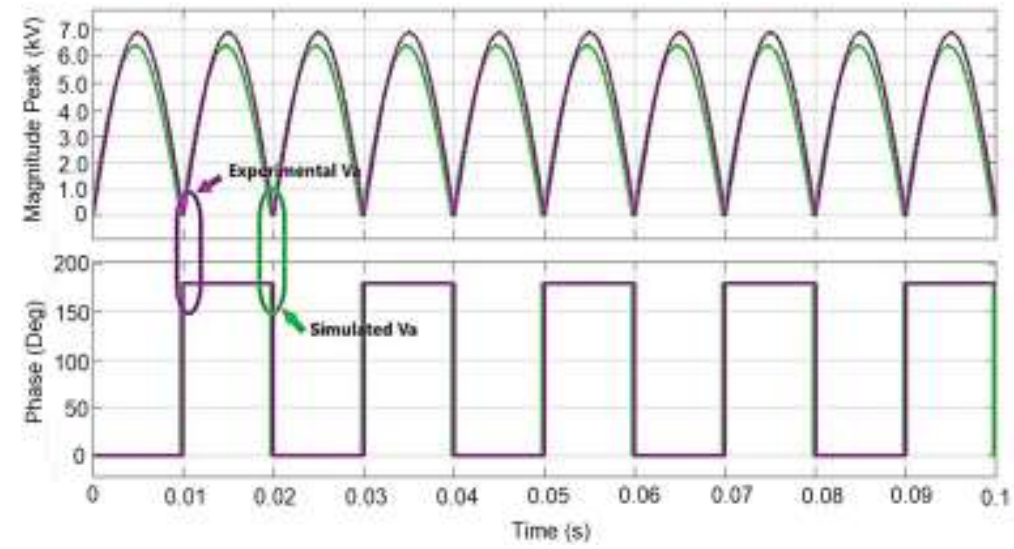

Fig. 16: Magnitude and phase of the microgrid.

In addition, the lowpass LCL microgrid filter offers high filtering performances with losses, synchronization, size, weight, and cost. Also, the experimental results are relatively similar to those gained in simulated results. Finally, it should be known that the experimental results specify the PSI switching performances and reliability of the designed PLL based synchronous controller with lowpass microgrid LCL output filter to reduce the loss and increase the system's overall efficiency.

\section{CONCLUSIONS}

The finding shows that, a series of switch-based IGBT/Diode PSI is designed and the proposed control system is simulated and experimental. The main influence of this design to integrate the PSI with the microgrid system by connecting the LCL filter with the aid of a PLL based current controller. The PSI output current is increased by connecting IGBT/Diodes switches in series and the stability of the system is improved. It is observed that the total harmonics distortion is $1.61 \%$ THD and phase angle is $4.35^{\circ}$, which is lower than maximum permissible distortion $\left(<5 \%\right.$ THD and $\left.<5^{\circ}\right)$ as per requirements of IEEE standard. The PSI output voltage and current of the THD are reduced from $44 \%$ to $2 \%$ which is $42 \%$ THD of reduced in both cases. On the other hand, simulated and experimental results show the analysis of PLL based PWM control system. The PSI phase angle is developed from $34.39^{\circ}$ to $4.35^{\circ}$ which is $30 \%$ improved in the PSI output voltage which shows the overall PSI system efficiency is $95.61 \%$. Thus, the proposed PSI inverter system can be implemented in large power systems and long power transmission and destitution systems as well.

\section{ACKNOWLEDGMENTS}

This research has been supported by the Malaysian Ministry of Education through the Fundamental Research Grant Scheme under the project ID: FRGS19-054-0662. 


\section{REFERENCES}

[1] Rahman T., Motakabber, S. M. A., \& Ibrahimy, M. I. (2016, July). Phase synchronous inverter for microgrid system. In 2016 International Conference on Computer and Communication Engineering (ICCCE) (pp. 167-171). IEEE.

[2] Huangfu Y, Pang S, Nahid-Mobarakeh B, Guo L, Rathore AK, Gao F. (2018). Stability Analysis and Active Stabilization of On-board DC Power Converter System with Input Filter. IEEE Trans. on Industrial Electronics, 65(1):790-799.

[3] Gomes CC, Cupertino AF, Pereira HA. (2018). Damping techniques for grid-connected voltage source converters based on LCL filter: An overview. Renewable and Sustainable Energy Reviews, 81:116-135.

[4] Dasgupta S, Mohan SN, Sahoo SK, Panda SK. (2013). Lyapunov function-based current controller to control active and reactive power flow from a renewable energy source to a generalized three-phase microgrid system. IEEE Trans. on Industrial Electronics, 60(2):799-813.

[5] Rahman T, Ibrahimy MI, Motakabber SM, Mostafa MG. (2014). Three phase three-layer phase synchronous inverter for microgrid system. In Computer and Communication Engineering (ICCCE), pp 44-47.

[6] Cao Y, Xu Y, Li Y, Yu J, Yu J. (2017). A Lyapunov stability theory-based control strategy for three-level shunt active power filter. Energies, 10(1):112.

[7] Rahman T., Motakabber, S. M. A., \& Ibrahimy, M. I. (2017). A Zero Crossing PWM Controller of a Full Bridge Single Phase Synchronous Inverter for Microgrid Systems. International Journal of Engineering and Information Systems, 1(6), 202-211.

[8] Yue Y, Chen Y, Luo A, Ma F, Xu Q, He Z. (2017). Robust predictive dual-loop control method based on Lyapunov function stability and energy equilibrium though double-core processors for active power filter. International Journal of Electrical Power \& Energy Systems, 89:69-81.

[9] Rahman T, Ibrahimy M I, Motakabber S M A. (2017). Synchronization of output voltage waveforms in phase synchronous inverter with LCL filter for smart grid systems. In 3rd International Conference on Science and Social Research, pp. 6-7.

[10] Costa BL, Bacon VD, da Silva SA, Angélico BA. (2017). Tuning of a PI-MR controller based on differential evolution metaheuristic applied to the current control loop of a shuntAPF. IEEE Trans. on Industrial Electronics, 64(6):4751-4761.

[11] Rahman T, Motakabber SM, Ibrahimy MI. (2016) Design of a switching mode three-phase inverters. In Computer and Communication Engineering (ICCCE), pp.155-160.

[12] Jayalath S, Hanif M. (2017). Generalized LCL-filter design algorithm for grid-connected voltage-source inverter. IEEE Trans. on Industrial Electronics, 64(3):1905-1915.

[13] Rahman T, Motakabber S M A, Ibrahimy M I. (2016). Low noise inverter for polyphase microgrid system. In Computer and Communication Engineering (ICCCE), pp172-176.

[14] Abdelrahem, M., Hackl, C. M., \& Kennel, R. (2018). Finite position set-phase locked loop for sensorless control of direct-driven permanent-magnet synchronous generators. IEEE Transactions on Power Electronics, 33 (4), 3097-3105.

[15] Rahman T., Motakabber, S. M. A., Ibrahimy, M. I., \& Rahman, M. W. (2017). An Enhanced Zero Crossing Based HVAC Phase Synchronous Inverter for Electrostatic Generator in Microgrid Systems. Indonesian Journal of Electrical Engineering and Informatics (IJEEI), 5(4), 285-294.

[16] Mondal, A., \& Illindala, M. S. (2018). Improved frequency regulation in an islanded mixed source microgrid through coordinated operation of DERs and smart loads. IEEE Transactions on Industry Applications, 54(1), 112-120.

[17] Rahman T, Motakabber SMA, Ibrahimy MI. (2017). Design and Simulation of a PWM Based Phase Synchronous Inverter for Utility Grid Systems with $20 \mathrm{~km}$ Feeder Line. Scientific Research Journal, 14(2):17-34. 